\title{
The crystal structure of cyanotrichite
}

\author{
Stuart J. Mills ${ }^{1, *}$, Andrew G. Christy $^{2}$, Fernando Colombo ${ }^{3}$ and Jason R. Price ${ }^{4}$ \\ ${ }^{1}$ Geosciences, Museum Victoria, GPO Box 666, Melbourne, Victoria 3001, Australia \\ 2 Centre for Advanced Microscopy and Department of Applied Mathematics, Research School of Physics and \\ Engineering, Australian National University, Canberra, ACT 0200, Australia \\ 3 CICTERRA-CONICET and Cátedra de Mineralogía, Facultad de Ciencias Exactas, Físicas y Naturales, \\ Universidad Nacional de Córdoba, Vélez Sarsfield 1611 (X5016GCA), Córdoba, Argentina \\ 4 Australian Synchrotron, 800 Blackburn Road, Clayton, Victoria 3168, Australia
}

[Received 2 December 2014; Accepted 19 February 2015; Associate Editor: G. D. Gatta]

\section{ABSTRACT}

We report the single-crystal average structure of cyanotrichite, $\mathrm{Cu}_{4} \mathrm{Al}_{2}\left[\mathrm{SO}_{4}\right](\mathrm{OH})_{12}\left(\mathrm{H}_{2} \mathrm{O}\right)_{2}$, from the Maid of Sunshine mine, Arizona, USA. Cyanotrichite crystallizes in space group $C 2 / m$, with the unitcell parameters $a=12.625(3), b=2.8950(6), c=10.153(2) \AA$ and $\beta=92.17(3)^{\circ}$. All non-hydrogen atoms were located and refined to $R_{1}=0.0394$ for all 584 observed reflections $\left[F_{\mathrm{o}}>4 \sigma F_{\mathrm{o}}\right.$ ] and 0.0424 for all 622 unique reflections. The cyanotrichite structure consists of a principal building unit of a three-wide $\left[\mathrm{Cu}_{2} \mathrm{Al}(\mathrm{OH})_{6}\right]$ ribbon of edge-sharing $\mathrm{Cu}$ and $\mathrm{Al}$ polyhedra $\| \mathbf{b}$, similar to that found for camerolaite. The ribbons lie in layers $\|(001)$ and between these layers, while $\mathrm{SO}_{4}$ tetrahedra and $\mathrm{H}_{2} \mathrm{O}$ molecules form rods running $\| \mathbf{b}$. A hydrogen-bonding scheme is also proposed.

A sample of cyanotrichite from the Cap Garonne mine, Le Pradet, France, showed a $4 b$ superstructure with the following unit cell: space group $P 2 / m, a=12.611(2) \AA, b=11.584(16)=$ $4 \times 2.896(4) \AA, c=10.190(1) \AA$ and $\beta=92.29(6)^{\circ}$. The supercell could not be refined in detail, but nevertheless imposes constraints on the local structure in that while the space-group symmetry prevents full order of $\mathrm{SO}_{4}$ and $\mathrm{H}_{2} \mathrm{O}$ in the $4 \mathrm{~b}$ supercell, it requires that the sequence of species along any given rod is $\left[-\mathrm{SO}_{4}-\mathrm{SO}_{4}-\left(\mathrm{H}_{2} \mathrm{O}\right)_{2}-\left(\mathrm{H}_{2} \mathrm{O}\right)_{2}-\right]$ rather than $\left[-\mathrm{SO}_{4}-\left(\mathrm{H}_{2} \mathrm{O}\right)_{2}-\mathrm{SO}_{4}-\left(\mathrm{H}_{2} \mathrm{O}\right)_{2}-\right]$.

KEYWORDs: cyanotrichite, camerolaite, carbonatecyanotrichite, khaidarkanite, merotype, superstructure, crystal structure, synchrotron.

\section{Introduction}

RECENTLY, we solved the crystal structure of camerolaite from a crystal from the Tistoulet mine, France, and described the structural variation in the cyanotrichite family of merotypes (Mills et al., 2014). In that paper, cyanotrichite was hypothesized to be isotypic with camerolaite, khaidarkanite and carbonatecyanotrichite. In the structures of camerolaite and khaidarkanite, edgesharing octahedral ribbons $\mathrm{Cu}_{2} \mathrm{Al}\left(\mathrm{O}, \mathrm{OH}, \mathrm{H}_{2} \mathrm{O}\right)_{8}$ form hydrogen-bonded layers \|| (001) (Hager et al., 2009; Mills et al., 2014), while additional

* E-mail: smills@museum.vic.gov.au DOI: 10.1180/minmag.2015.079.2.10 species partly occupy sites between the layers. In camerolaite, $\mathrm{Cu}_{6} \mathrm{Al}_{3}(\mathrm{OH})_{14}\left(\mathrm{H}_{2} \mathrm{O}\right)_{2} \mathrm{O}_{2}+$ $\left(\mathrm{Sb} \square_{2}\right)_{\Sigma 3}\left(\mathrm{~S} \square_{2}\right)_{\Sigma 3}\left[(\mathrm{OH})_{4} \mathrm{O}_{2}\right]_{\Sigma 6}=$ $\mathrm{Cu}_{6} \mathrm{Al}_{3}\left[\mathrm{Sb}(\mathrm{OH})_{6}\right]\left[\mathrm{SO}_{4}\right](\mathrm{OH})_{18}\left(\mathrm{H}_{2} \mathrm{O}\right)_{2}$, interlayer $\left[\mathrm{Sb}(\mathrm{OH})_{6}\right]^{-}$and $\mathrm{SO}_{4}^{2-}$ groups alternate along rods $\| \mathbf{b}$, resulting in local tripling of the periodicity. In khaidarkanite, $\mathrm{Cu}_{4} \mathrm{Al}_{2}(\mathrm{OH})_{14}\left(\mathrm{H}_{2} \mathrm{O}\right)_{2}+(\mathrm{Al} \square)_{\Sigma 2}\left(\mathrm{~F}_{3} \square\right)_{\Sigma 4}=$ $\mathrm{Cu}_{4} \mathrm{Al}_{3} \mathrm{~F}_{3}(\mathrm{OH})_{14}\left(\mathrm{H}_{2} \mathrm{O}\right)_{2}, \quad \mathrm{AlF}_{4}\left(\mathrm{H}_{2} \mathrm{O}\right)_{2}$ octahedra bridge the (001) layers, playing a role analogous to that of $\left[\mathrm{Sb}(\mathrm{OH})_{6}\right]^{-}$in camerolaite (Hager et al., 2009).

In camerolaite, the structural rods with $3 b$ periodicity show no long-range ordering of their relative phases. Thus, the superperiod of the rods gives rise only to diffuse scattering at $k=n / 3(n=$ 
integer), rather than to sharp superstructure Bragg peaks. Currently, there is no evidence for even short-range order in khaidarkanite, but Mills et al. (2014) hypothesized that the $1: 3$ ratio of $\mathrm{Al}: \mathrm{F}$ is achieved by the bridging octahedra occurring in edge-sharing pairs $\mathrm{Al}_{2} \mathrm{~F}_{6}\left(\mathrm{H}_{2} \mathrm{O}\right)_{4}$, alternating along b with pairs of vacant interlayer $\mathrm{Al}$ sites, and hence leading to a local quadrupling of periodicity.

Cyanotrichite is the member of this group whose formula is generated by $\mathrm{Cu}_{4} \mathrm{Al}_{2}(\mathrm{OH})_{12}\left(\mathrm{H}_{2} \mathrm{O}\right)_{2} \mathrm{O}_{2}+(\mathrm{S} \square)_{\Sigma 2}\left(\mathrm{O}_{2} \square_{2}\right)_{\Sigma 4}=$ $\mathrm{Cu}_{4} \mathrm{Al}_{2}\left[\mathrm{SO}_{4}\right](\mathrm{OH})_{12}\left(\mathrm{H}_{2} \mathrm{O}\right)_{2}$. Mills et al. (2014) predicted that cyanotrichite has a structure in which $\mathrm{SO}_{4}^{2-}+2 \mathrm{H}_{2} \mathrm{O}$ repeat along b within the interlayer and that the up/down sense of the sulfate tetrahedron is not necessarily ordered. This results in the minimum periodicity along any given sulfate chain being $2 b$. To test this hypothesis, we have investigated a sample of cyanotrichite from the Maid of Sunshine mine, Cochise County, Arizona, USA (M37263, housed in the Geoscience collections of Museum Victoria; Fig. 1a) and a sample from the Cap Garonne mine, Var, France (M53333, Museum Victoria; Fig. 1b), for which the occurrence of weak reflections corresponding to a $4 b$ superstructure was noted in Mills et al. (2014). The use of synchrotron X-rays to elucidate the structure was essential, given the small size and generally poor quality of cyanotrichite needles (Fig. 1). Cyanotrichite from both localities looks very similar, occurring as clusters of translucent, blue needles. Longer needles are sometimes bent and become opaque, presumably due to microfractures.

\section{Experimental}

\section{Spectroscopy}

The infrared spectra were obtained using a Bruker Alpha Fourier transform infrared (FTIR) spectrometer with a diamond Attenuated Total Reflectance attachment (ATR), deuterated triglycine sulfate (DTGS) detector, $4 \mathrm{~cm}^{-1}$ resolution and $4000-450 \mathrm{~cm}^{-1}$ range. The samples were placed on the ATR crystal and pressure exerted by screwing the pressure clamp onto the sample to ensure maximum contact with the ATR crystal. 128 scans were taken for each item and co-added.

\section{Single-crystal $X$-ray diffraction}

A $50 \mu \mathrm{m} \times 20 \mu \mathrm{m} \times 2 \mu \mathrm{m}$ needle of the cyanotrichite from the Maid of Sunshine mine was mounted on a nylon loop to minimize diffraction from the sample mount for X-ray data collection on the micro-focus macromolecular beam line, MX2, of the Australian Synchrotron. Data were collected at $100 \mathrm{~K}$ using an ADSC Quantum 315r detector and monochromatic radiation with a wavelength of $0.71073 \AA$. A $\varphi$ scan was employed, with frame widths of $1^{\circ}$ and a counting time of $1 \mathrm{~s}$ per frame. The data were integrated in $P 1$ using $X D S$ (Kabsch, 2010).
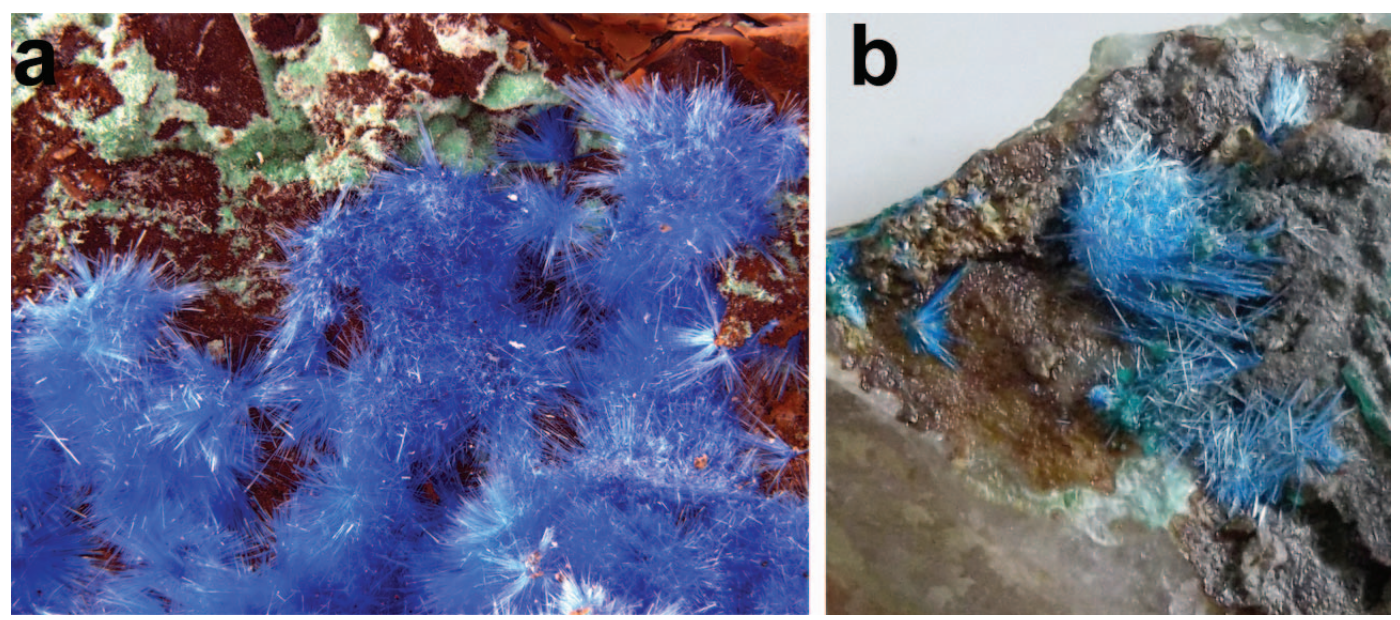

FIG. 1. (a) Intergrown crystals of cyanotrichite with chalcophyllite from the Maid of Sunshine mine. Field of view 1 $\mathrm{cm}$ across. Specimen M37263, Bill Birch photograph. (b) Intergrown crystals of cyanotrichite with parnauite from Cap Garonne. Field of view $7 \mathrm{~mm}$ across. FC specimen. 
TABLE 1. X-ray data collection and structure refinement details for cyanotrichite from the Maid of Sunshine mine.

$\begin{array}{ll}\text { Structural formula } & {\left[\mathrm{Cu}_{4} \mathrm{Al}_{2}(\mathrm{OH})_{12}\right]\left[\mathrm{SO}_{4}\right]\left(\mathrm{H}_{2} \mathrm{O}\right)_{2}} \\ \text { Space group } & C 2 / m(\mathrm{No} .12) \\ \text { Unit-cell dimensions } & \\ a(\AA) & 12.625(3) \\ b(\AA) & 2.8950(6) \\ c(\AA) & 10.153(2) \\ \beta\left({ }^{\circ}\right) & 92.17(3) \\ V(\AA)^{3} & 370.82(13) \\ Z & 1 \\ \text { Absorption coefficient } & 9.103 \mathrm{~mm}^{-1} \\ F(000) & 491 \\ o \text { range } & 2.01-29.96 \\ \text { Index ranges } & \\ h & -17 \leqslant h \leqslant 17 \\ k & -4 \leqslant k \leqslant 4 \\ l & -14 \leqslant l \leqslant 13 \\ \text { Reflections collected } & 622 \\ \text { Reflections with } F>4 \sigma(F) & 584 \\ \text { Refinement method } & \text { Full-matrix least-squares on } \mathrm{F}^{2} \\ \text { Parameters refined } & 52 \\ \text { Gof } & 1.152 \\ \text { Final } R \text { indices }\left[F_{\mathrm{o}}>4 \sigma(F)\right] & R_{1}=0.0394, \mathrm{w} R_{2}=0.1070 \\ R \text { indices }(\text { all data) } & \mathrm{R}_{1}=0.0424, \mathrm{w} R_{2}=0.1093 \\ \text { Largest diff. peak / hole } & 1.137 /-0.961 \text { el } / \AA^{3}\end{array}$

XPREP (Bruker, 2001) gave a space group of $C 2 /$ $m$, consistent with $E$-statistics that indicated a centrosymmetric space group. The absorption correction was carried out with SADABS (Bruker, 2001), giving 3584 reflections with an $R_{\text {int }}$ of 0.0468 . The heavy $\mathrm{Cu}, \mathrm{Al}$ and $\mathrm{S}$ atoms were found using SHELXS-97 (Sheldrick, 2008). All other atoms were then located via subsequent
difference-Fourier syntheses during the refinement, performed using SHELXL-97 (Sheldrick, 2008). Details of data collection and structure refinement are provided in Table 1. Fractional coordinates and isotropic atom displacement parameters are provided in Table 2, with anisotropic displacement parameters for atoms on fully occupied sites reported in Table 3.

TABLE 2. Atom coordinates and displacement parameters $\left(\AA^{2}\right)$ for cyanotrichite.

\begin{tabular}{llclcc}
\hline Atom & $x$ & $y$ & \multicolumn{1}{c}{$z$} & Occupancy & $U_{\text {eq }}$ \\
\hline $\mathrm{Al}$ & $1 / 2$ & $1 / 2$ & 0 & 1 & $0.0111(4)$ \\
$\mathrm{Cu}$ & $0.64527(4)$ & 0 & $0.79654(6)$ & 1 & $0.0131(3)$ \\
$\mathrm{S}$ & $0.5881(3)$ & $1 / 2$ & $0.5003(5)$ & 0.25 & $0.0140(8)$ \\
$\mathrm{O} 1$ & $0.5383(3)$ & $1 / 2$ & $0.8168(3)$ & 1 & $0.0129(6)$ \\
$\mathrm{O} 2$ & $0.4055(3)$ & 0 & $0.9748(3)$ & 1 & $0.0123(6)$ \\
$\mathrm{O} 3$ & $0.7457(3)$ & $1 / 2$ & $0.7922(4)$ & 1 & $0.0158(7)$ \\
$\mathrm{O} 4$ & $0.6309(6)$ & $0.078(4)$ & $0.5639(8)$ & 0.25 & $0.019(2)$ \\
$\mathrm{O} 5$ & $0.6134(6)$ & $1 / 2$ & $0.3593(17)$ & 0.25 & $0.021(3)$ \\
$\mathrm{O} 6$ & $0.5315(11)$ & $1 / 2$ & $0.4920(14)$ & 0.25 & $0.019(3)$ \\
$\mathrm{O} 7$ & $0.6077(8)$ & $0.680(5)$ & $0.3926(9)$ & 0.25 & $0.019(2)$ \\
& & & & & \\
\hline
\end{tabular}


TABLE 3. Anisotropic displacement parameters $\left(\AA^{2}\right)$ for cyanotrichite.

\begin{tabular}{lllllrl}
\hline Atom & \multicolumn{1}{c}{$U^{11}$} & \multicolumn{1}{c}{$U^{22}$} & \multicolumn{1}{c}{$U^{33}$} & $U^{23}$ & \multicolumn{1}{c}{$U^{13}$} & $U^{12}$ \\
\hline $\mathrm{Al}$ & $0.0092(8)$ & $0.0094(9)$ & $0.0145(8)$ & 0 & $-0.0003(6)$ & 0 \\
$\mathrm{Cu}$ & $0.0095(3)$ & $0.0094(4)$ & $0.0202(4)$ & 0 & $-0.0004(2)$ & 0 \\
$\mathrm{~S}$ & $0.0082(18)$ & $0.014(2)$ & $0.020(2)$ & 0 & $0.0014(14)$ & 0 \\
$\mathrm{O} 1$ & $0.0123(14)$ & $0.0117(16)$ & $0.0148(14)$ & 0 & $0.0008(11)$ & 0 \\
O2 & $0.0100(13)$ & $0.0095(15)$ & $0.0173(15)$ & 0 & $-0.0001(11)$ & 0 \\
O3 & $0.0130(14)$ & $0.0145(17)$ & $0.0200(16)$ & 0 & $0.0015(11)$ & 0 \\
\hline
\end{tabular}

\section{Structure refinement}

Initial refinement of the $S$ site showed that it was not fully occupied. Unconstrained refinement of the site yielded $27(2) \% \mathrm{~S}$, which is within error of the $25 \%$ for the ideal composition with $1 \mathrm{~S}$ per $4 \mathrm{Cu}$ and $2 \mathrm{Al}$. The $S$ site occupancy was therefore fixed at $25 \%$ in later refinements. Oxygen atoms $\mathrm{O} 5$ and $\mathrm{O} 6$ were located in the difference-Fourier maps, and are also $25 \%$ occupied, with $\mathrm{S}-\mathrm{O}$ distances implying that they are apical oxygen atoms of the sulfate tetrahedron. Note that $\mathrm{O} 6$ is at $1.515 \AA$ from the sulfur to which it is bonded, but is also at $0.72 \AA$ from another sulfur atom, attached to a $\mathrm{Cu}-\mathrm{Al}$ ribbon on the other side of the interlayer gap. The two sulfur sites and their attendant oxygen atoms form a pair of $\mathrm{SO}_{4}$ tetrahedra that interpenetrate one another, related by a diad axis in the average structure, in which the $\mathrm{S}$ atoms are only $2.22 \AA$ apart. Hence, the two $S$ sites (and their attendant O4-O6 sites) cannot both be occupied simultaneously (see discussion below).

As was the case for the structure of camerolaite (Mills et al., 2014), the two oxygen atoms (O4) of the sulfate tetrahedron bridge two adjacent $\mathrm{Cu}\left(\mathrm{OH}, \mathrm{O}, \mathrm{H}_{2} \mathrm{O}\right)_{6}$ octahedra along the edge of the $\mathrm{Cu}-\mathrm{Al}$ ribbon. If the sulfate $\mathrm{S}-\mathrm{O}$ distance is close to the grand average value $1.459 \AA$ of Hawthorne et al. (2000), then the $\mathrm{O} \cdots \mathrm{O}$ distance along the tetrahedral edge must be close to $\sqrt{ }(8 / 3) \times 1.459=2.382 \AA$, significantly less than the $b$ parameter $(\sim 2.9 \AA)$. Hence, O4 oxygen atoms that are bonded to a sulfur atom cannot be located at the average $\mathrm{O} 4$ position with $y=0$, but must be split between two sites that are displaced towards the nearby sulfur by $\sim \pm 0.08 \mathbf{b}$; the $\mathrm{O} 4$ position was refined accordingly. The split sites are separated by only $0.45 \AA$, so these sites also cannot be occupied simultaneously.

In camerolaite, the oxygen atom corresponding to $\mathrm{O} 4$ was in fact split between the two 'sulfate' positions (25\% each) and a central position $(50 \%)$ corresponding to $\mathrm{H}_{2} \mathrm{O}$ bonded to $\mathrm{Cu}$, with no sulfur nearby. However, attempts to refine a similar model for $\mathrm{O} 4$ in cyanotrichite were not successful, resulting in excessively large displacement parameters. The total occupancy at $\mathrm{O} 4$ refined to $50 \%$ rather than $100 \%$, implying that only the 'sulfate' split sites exist in cyanotrichite, not the 'water' site, therefore the structural water must be located elsewhere.

The water molecules were located when it was noted that another difference from the camerolaite structure was the reproducible occurrence in cyanotrichite refinements of substantial electron density maxima $\left(\sim 2 e^{-}\right)$on either side of sulfate oxygen O5. These are so close to O5 (0.63 $\AA$ ) that they cannot be occupied when a $\mathrm{SO}_{4}$ tetrahedron is present; they are interpreted to be $25 \%$ occupied oxygen sites, representing the location of the structural water in cyanotrichite, given that it is not bonded directly to $\mathrm{Cu}$. The additional site is labelled $\mathrm{O} 7$ here. It will be seen below that $\mathrm{O} 7$ is at distances suitable for making hydrogen bonds to oxide anions of the sulfate tetrahedron and hydroxide anions $\mathrm{O} 1$ and $\mathrm{O} 3$ in nearby $\mathrm{Cu}-\mathrm{Al}$ ribbons.

Thus, all atoms of the $\mathrm{Cu}_{4} \mathrm{Al}_{2}(\mathrm{OH})_{12}$ $\left[\mathrm{SO}_{4}\right] \cdot 2 \mathrm{H}_{2} \mathrm{O}$ formula unit except hydrogen are accounted for, in the refinement of this study. The final model, with $\mathrm{Cu}, \mathrm{Al}, \mathrm{S}$ and $\mathrm{O} 1-\mathrm{O} 3$ refined anisotropically and $\mathrm{O} 4-\mathrm{O} 7$ refined isotropically, converged to $R_{1}=0.0394$ for all 252 observed reflections $\left[F_{\mathrm{o}}>4 \sigma F_{\mathrm{o}}\right]$ and 0.0424 for all 324 unique reflections in $C 2 / m$, with the unit-cell parameters $a=12.625(3) \AA, b=2.8950(6) \AA, c=$ $10.153(2) \AA$ and $\beta=92.17(3)^{\circ}$.

Selected interatomic distances are shown in Table 4, while Table 5 shows bond valences and bond-valence sums between $\mathrm{Cu}, \mathrm{Al}, \mathrm{S}$ and O1-O6 using the bond-valence parameters of Brese and O'Keeffe (1991). The bond-valence 
TABLE 4. Selected bond distances (A) for cyanotrichite.

\begin{tabular}{rlrl}
\hline $\mathrm{Al}-\mathrm{O} 1$ & $1.939(3) \times 2$ & $\mathrm{Cu}-\mathrm{O} 1$ & $1.996(2) \times 2$ \\
$-\mathrm{O} 2$ & $1.887(2) \times 4$ & $-\mathrm{O} 2$ & $2.431(3)$ \\
$<\mathrm{Al}-\mathrm{O}>$ & 1.904 & $-\mathrm{O} 3$ & $1.926(2) \times 2$ \\
& & $-\mathrm{O} 4^{*}$ & $2.373(8)$ \\
$\mathrm{S}-\mathrm{O} 4$ & $1.474(10) \times 2$ & $<\mathrm{Cu}-\mathrm{O}>$ & $2.055,2.108^{*}$ \\
$-\mathrm{O} 5$ & $1.479(18)$ & & \\
$-\mathrm{O} 6$ & $1.515(16)$ & & \\
$<\mathrm{S}-\mathrm{O}>$ & 1.486 & & \\
\hline
\end{tabular}

* Only applies if $\mathrm{Cu}$ is bonded to $\mathrm{SO}_{4}$.

sum for $\mathrm{Cu}$ is an average of the values 2.006 valence units (vu) for a 5-coordinate cation (no nearby O4) and $2.159 \mathrm{vu}$ for a 6-coordinate cation; both sums are quite acceptable, as are those for $\mathrm{Al}$ and $\mathrm{S}$. The bond-valence sums on O1-O6 are all intermediate between 1 and 2 $\mathrm{vu}$, as would be expected for $\mathrm{OH}^{-}$and $\mathrm{O}^{2-}$ anions which participate in hydrogen bonding. The hydrogen atoms were not located in the crystal structure and could not be included in Table 6. Even though coordinates for the $\mathrm{H}$ atoms are not known, some features of the hydrogen bonding scheme can be deduced, as discussed below.

\section{Discussion}

\section{Infrared spectroscopy}

The IR spectrum of the Maid of Sunshine mine cyanotrichite shows strong bands at 1648, 1092, 1038, 916, 885, 781, 697, 656, 571, 491 and 422 $\mathrm{cm}^{-1}$, with weak but sharp peaks at 975 and 608 $\mathrm{cm}^{-1}$, shoulders at 1003,820 and $740 \mathrm{~cm}^{-1}$ and broad absorption of complex structure due to $\mathrm{O}-\mathrm{H}$ stretching modes spread over $2400-3650 \mathrm{~cm}^{-1}$, corresponding to the presence of $\mathrm{OH}^{-}$and $\mathrm{H}_{2} \mathrm{O}$ with a wide range of hydrogen- bonding strengths (Fig. 2). This is consistent with the IR spectra of the cyanotrichite sample M50793 of Mills et al. (2014), which showed the same features, particularly the $\mathrm{H}_{2} \mathrm{O}$ bend at 1648 and $\mathrm{SO}_{4}$ stretching bands at 1093 and $1035 \mathrm{~cm}^{-1}$. The lack of bands in the $1100-1500 \mathrm{~cm}^{-1}$ region is noteworthy, both confirming the lack of $\mathrm{CO}_{3}^{2-}$ within the sample, and supporting the inference that such bands, when observed, do arise from the presence of carbonate (Mills et al., 2014).

The IR spectrum of the Cap Garonne sample is compared with that of the Maid of Sunshine sample in Fig. $2 b$. In the $400-1100 \mathrm{~cm}^{-1}$ region, every band or shoulder of one spectrum has a correspondent at a very similar position in the other, although the relative intensities of features vary considerably. This may be due to different orientations of crystals crushed using the diamond ATR attachment. However, the $\mathrm{H}_{2} \mathrm{O}$ bend at $1648 \mathrm{~cm}^{-1}$ splits into two peaks at 1619 and $1682 \mathrm{~cm}^{-1}$ in the Cap Garonne sample, and the profile in the $\mathrm{O}-\mathrm{H}$ stretch region at $2400-3650 \mathrm{~cm}^{-1}$ is very different, which suggests that the $\mathrm{H}_{2} \mathrm{O}$ environments and/or hydrogen-bonding patterns may be different in the two samples.

TABLE 5. Bond valences and bond-valence sums for the cyanotrichite structure (excluding $\mathrm{O} 7$ and hydrogen atoms). The bond-valence parameters of Brese and O'Keeffe (1991) were used.

\begin{tabular}{llcccccc}
\hline & \multicolumn{1}{c}{ O1 } & \multicolumn{1}{c}{ O2 } & O3 & O4 & O5 & O6 & $\Sigma$ \\
\hline $\mathrm{Al}$ & $0.459 \times 2 \rightarrow$ & $0.528 \times 4 \rightarrow, \times 2 \downarrow$ & & & & & 3.032 \\
$\mathrm{Cu}$ & $0.425 \times 2$ & 0.131 & 0.513 & $\begin{array}{l}0.153 \times 1 / 2 \rightarrow \\
1.500 \times 2 \rightarrow\end{array}$ & 1.480 & 1.343 & 5.822 \\
$\mathrm{~S}$ & & & 1.083 \\
$\Sigma$ & 1.308 & 1.188 & 1.026 & 1.653 & 1.480 & 1.343 & \\
\hline
\end{tabular}


TABLE 6. Estimated positions of $\mathrm{H}$ atoms. The primary bonds from $\mathrm{H} 1-\mathrm{H} 3$ are to $\mathrm{O} 1-\mathrm{O} 3$ respectively; $\mathrm{H} 4$ and $\mathrm{H} 5$ make their short bonds to O7. Secondary bonds from $\mathrm{H} 1-\mathrm{H} 5$ are to O5/O7, O3, O5/O7, 04 and $\mathrm{O} 6$ respectively. $\mathrm{H} 3$ and $\mathrm{H} 5 y$-coordinates have been set at zero to avoid site splitting.

\begin{tabular}{lcccc}
\hline Atom & $x$ & $y$ & $z$ & Occupancy \\
\hline H1 & 0.485 & $1 / 2$ & 0.741 & 1 \\
H2 & 0.345 & 0 & 0.905 & 1 \\
H3 & 0.298 & 0 & 0.726 & 1 \\
H4 & 0.384 & 0.407 & 0.455 & 0.25 \\
H5 & 0.420 & 0 & 0.430 & 0.5
\end{tabular}

\section{Structural features of cyanotrichite}

The Maid of Sunshine cyanotrichite is confirmed to have as its principal building unit a three-wide ribbon of edge-sharing $\mathrm{Cu}$ and $\mathrm{Al}$ polyhedra $\| \mathbf{b}$, similar to that found for camerolaite (Mills et al., 2014) and proposed for the group as a whole by Hager et al. (2009). However, in cyanotrichite, the $\mathrm{Cu}$ is in 6-fold coordination only when bonding to a sulfate oxygen. The $\mathrm{Cu}$ atoms which do not have an associated $\mathrm{SO}_{4}$ tetrahedron are in squarepyramidal 5-fold coordination. Hence, the triple octahedral ribbon $\left[\mathrm{Cu}_{2} \mathrm{Al}\left(\mathrm{OH}, \mathrm{O}, \mathrm{H}_{2} \mathrm{O}\right)_{8}\right]$ is not a feature shared by the whole cyanotrichite group. The building unit common to all group members is actually a $\left[\mathrm{Cu}_{2} \mathrm{Al}(\mathrm{OH})_{6}\right]$ ribbon in which the $\mathrm{Cu}$ have 5-fold coordination, which may be augmented to 6-fold through bonding to additional $\mathrm{H}_{2} \mathrm{O}$ or groups such as $\left[\mathrm{SO}_{4}\right]^{2-}$ (in cyanotrichite and camerolaite), $\left[\mathrm{Sb}(\mathrm{OH})_{6}\right]^{-}$(camerolaite) or $\left[\mathrm{Al}_{2} \mathrm{~F}_{6}\left(\mathrm{H}_{2} \mathrm{O}\right)_{4}\right]^{0}$ (khaidarkanite).

The average structure of Maid of Sunshine cyanotrichite is shown in Fig. 3. The fully ordered and fully occupied part of the structure is represented by $\mathrm{CuO}_{5}$ and $\mathrm{AlO}_{6}$ polyhedra forming edge-sharing ribbons $\| \mathbf{b}$, which lie in layers $\|$ (001) (Fig. 3a). Between the layers, $\mathrm{SO}_{4}$ tetrahedra and $\mathrm{H}_{2} \mathrm{O}$ molecules form rods, also running $\| \mathbf{b}$ (Fig. $3 b$ ). These sites are only $25 \%$ occupied, but necessarily show short-range order, which is discussed below. Strong hydrogen bonding between adjacent ribbons is enabled through $b / 2$ shifts between adjacent ribbons (see below); this connects ribbons into layers $\|(001)$ and produces a unit cell that is $C$-centred or nearly so (Fig. 3c).

\section{Short-range order of sulfate and water}

All $\mathrm{SO}_{4}$ and $\mathrm{H}_{2} \mathrm{O}$ sites ( $\mathrm{S}$ and $\mathrm{O}_{4-\mathrm{O}}$ ) are partially occupied in the average structure. Most of these sites also are at close distances to other sites, which preclude simultaneous occupation of the two. The resulting short-range ordering conditions are shown diagrammatically in Fig. 4 and summarized as follows.

(1) If a $S$ site is occupied, then the corresponding $\mathrm{O} 4(\times 2), \mathrm{O} 5$ and $\mathrm{O} 6$ sites that complete the $\mathrm{SO}_{4}$ tetrahedron are also occupied. Otherwise, these sites are vacant.

(2) The diad axes of the structure relate 'lower' $\mathrm{SO}_{4}$ tetrahedra bonded through $\mathrm{O} 4$ to $\mathrm{Cu}$ of a $\mathrm{Cu}-\mathrm{Al}$ ribbon below and 'upper' $\mathrm{SO}_{4}$ bonded to $\mathrm{Cu}$ of a ribbon above. The two tetrahedra interpenetrate, and the $S$ sites are only $2.22 \AA$ apart, so only one or the other or neither of these $\mathrm{SO}_{4}$ tetrahedra may be present in any given unitcell wide segment of a $\mathrm{SO}_{4}-\mathrm{H}_{2} \mathrm{O}$ rod.

(3) $\mathrm{O} 4$ is not at $y=0$, but is split into two sites $0.45 \AA$ apart (Fig. $4 b$ ). These are only occupied if the nearby $S$ site is occupied, but the close separation means that if one 'upper' or 'lower' $\mathrm{SO}_{4}$ is occupied, then the corresponding sites in the next unit cells at $\pm \mathbf{b}$ must be vacant.

(4) Each $3 \AA$-wide (i.e. one $b$ repeat) segment of a $\mathrm{SO}_{4}-\mathrm{H}_{2} \mathrm{O}$ rod contains four water sites (O7). These are $1.51 \AA$ away from O6 of one $\mathrm{SO}_{4}$ in the same segment and $0.63 \AA$ away from $\mathrm{O} 5$ of the other $\mathrm{SO}_{4}$ (Fig. $4 b$ ); therefore, none of the $\mathrm{O} 7$ can be present if an $\mathrm{SO}_{4}$ is present in that segment.

(5) Each O7 site is only $1.04 \AA$ from the nearest other $\mathrm{O} 7$ at the same height, and only $1.85 \AA$ from the $\mathrm{O} 7$ at the same height in the opposite direction along b. Therefore, occupation of an $\mathrm{O} 7$ site means that both adjacent $\mathrm{O} 7$ sites at the same height must be vacant (Fig. 4c). Along with points (3) and (4), this implies that each $3 \AA$ segment of a rod contains at most either one $\mathrm{SO}_{4}$ (in either 'up' or 'down' orientation) or two $\mathrm{H}_{2} \mathrm{O}$ (in one of two 


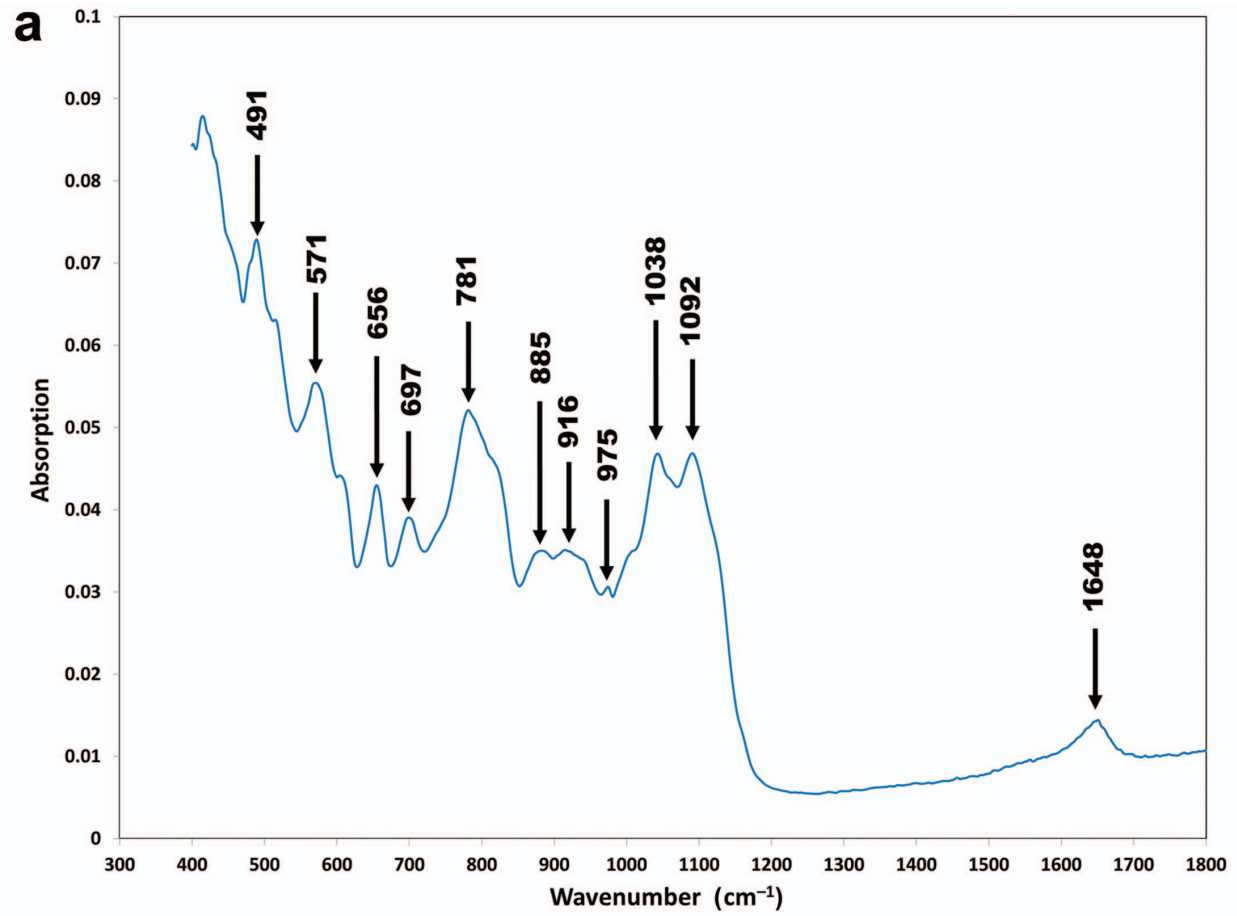

b

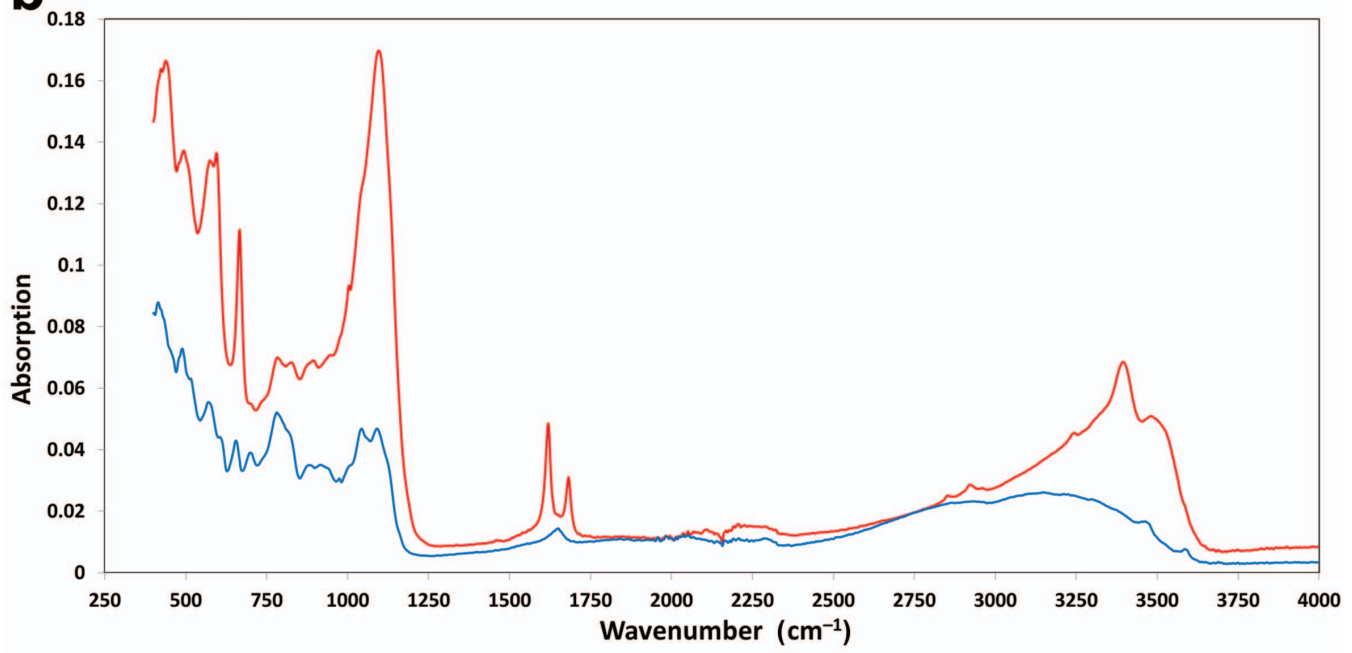

Fig. 2. (a) Low-wavenumber region of the infrared spectrum of Maid of Sunshine cyanotrichite, with principal bands indicated. (b) Infrared spectra of Maid of Sunshine cyanotrichite (blue) and Cap Garonne cyanotrichite (red).

configurations). The formula and average occupancies imply that the numbers of $\mathrm{SO}_{4}$ and $\mathrm{H}_{2} \mathrm{O}$ segments are equal.

(6) An O4 of a 'lower' $\mathrm{SO}_{4}$ is only $2.10 \AA$ away from the nearest 'upper' $\mathrm{O} 7$ of the adjacent segment (Fig. 4b). Therefore, these two sites cannot be occupied simultaneously and the orientation of an $\mathrm{SO}_{4}$ group in one segment and the $\mathrm{H}_{2} \mathrm{O}$ molecules in an adjacent segment are coupled. 

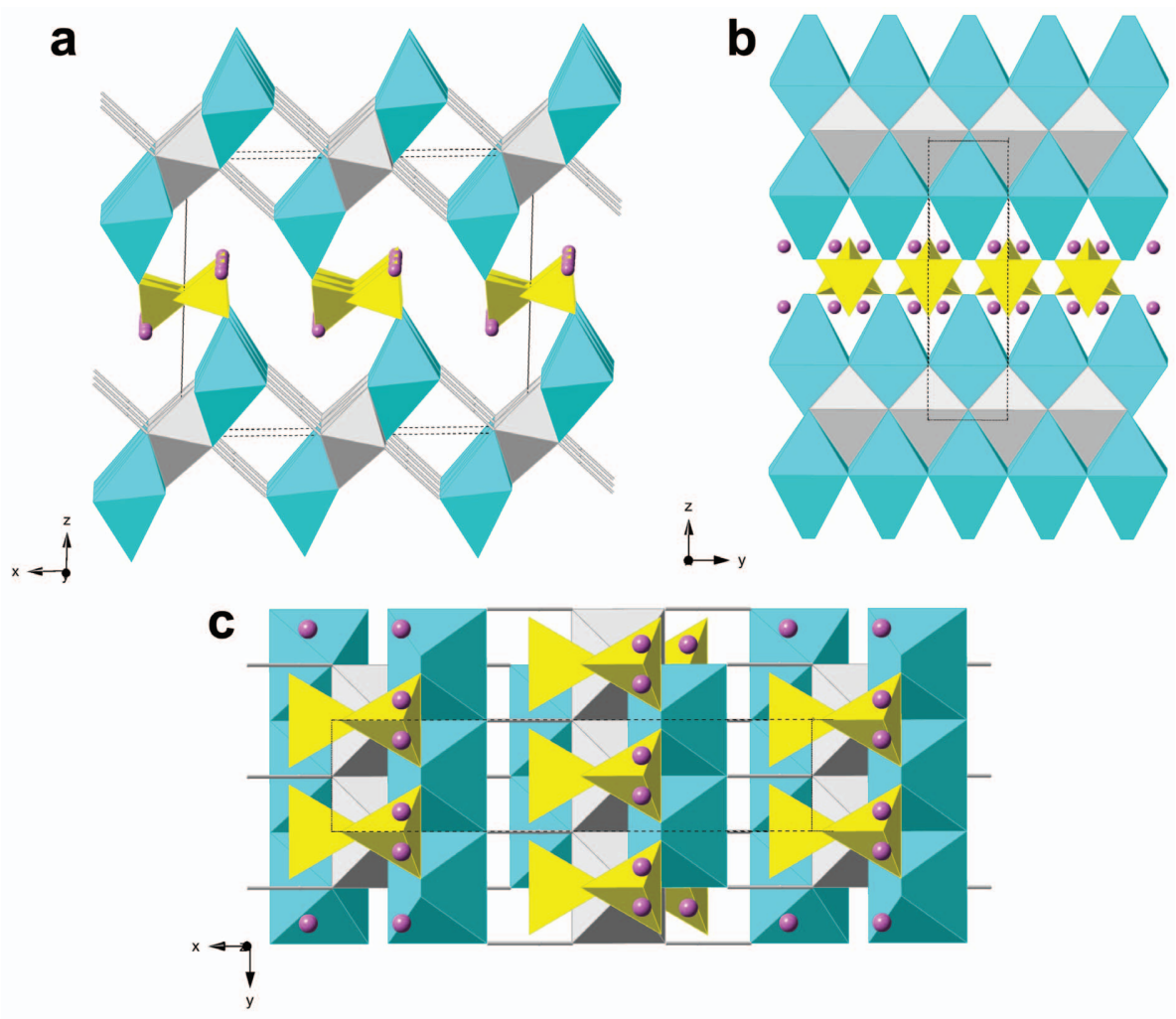

FIG. 3. Average structure of Maid of Sunshine cyanotrichite: $\mathrm{Al}-\mathrm{O}$ polyhedra are grey; $\mathrm{Cu}-\mathrm{O}$ polyhedra cyan; $25 \%$ occupied $\mathrm{SO}_{4}$ tetrahedra yellow; $25 \%$ occupied $\mathrm{O} 7$ (water) sites are pink spheres; $2.69 \AA \mathrm{A} 2 \cdots \mathrm{O} 3$ distances interpreted as hydrogen bonds are shown as grey 'sticks'; the unit cell is indicated by a black dashed line. ( $a$ ) View approximately down $\mathbf{b}$, showing layers of $\mathrm{Cu}-\mathrm{Al}$ ribbons $\|(001)$ with partly occupied $\mathrm{SO}_{4}$ and $\mathrm{H}_{2} \mathrm{O}$ in the interlayer gap. (b) View down a, emphasizing the rod of $\mathrm{SO}_{4}$ and $\mathrm{H}_{2} \mathrm{O} \| \mathbf{b}$ between $\mathrm{Cu}-\mathrm{Al}$ ribbons above and below. Note 'chisel' termination of $\mathrm{Cu}-\mathrm{O}$ polyhedron due to splitting of $\mathrm{O} 4$ site. (c) View down c, showing the $b / 2$ offset of successive $\mathrm{Cu}-\mathrm{Al}$ ribbons which allows them to hydrogen bond to their neighbours, forming a layer $\|(001)$ with a $C$-centred mesh.

\section{Hydrogen bonding in cyanotrichite}

It has been noted above that the fully-ordered $\mathrm{Cu}-\mathrm{Al}$ ribbons of the cyanotrichite structure are linked into layers $\|(001)$ by hydrogen bonding. Successive ribbons are displaced by $\mathbf{b} / 2$ such that the $\mathrm{O} 2$ oxygen of one ribbon is $2.688 \AA$ away from $\mathrm{O} 3$ of the next ribbon, and vice versa. This $\mathrm{O} \cdots \mathrm{O}$ distance is consistent with a $\mathrm{H} \cdots \mathrm{O}$ hydrogen bond of $\sim 0.21 \mathrm{vu}$ (Brown and Altermatt, 1985). As the bond-valence sums from cations exclusive of hydrogen on $\mathrm{O} 2$ and $\mathrm{O} 3$ are, respectively, 1.19 and $1.03 \mathrm{vu}$, the bond valence between $\mathrm{O} 2$ and its hydrogen $\mathrm{H} 2$ is significantly less than $1 \mathrm{vu}$, so $\mathrm{O} 2-\mathrm{H} 2$ is deduced to be the donor and $\mathrm{O} 3$ the acceptor. In that case, the bond $\mathrm{O} 3-\mathrm{H} 3$ must be directed away from the plane of the other $\mathrm{O} 3$ ligands $(2 \mathrm{Cu}+\mathrm{H} 2)$; this directs $\mathrm{O} 3-\mathrm{H} 3$ towards either a sulfate $\mathrm{O} 5(50 \%$ of the time; $\mathrm{O} 3 \cdots \mathrm{O} 5=$ $2.799 \AA)$ or a water $\mathrm{O} 7(50 \%$ of the time; O3 $\cdots$ O 5 $=2.840 \AA$ ). The $\mathrm{O} 5 / \mathrm{O} 7$ actually belong to a $\mathrm{SO}_{4}-\mathrm{H}_{2} \mathrm{O}$ rod above or below the next $\mathrm{Cu}-\mathrm{Al}$ ribbon in the a direction, so these $\mathrm{H}$ bonds contribute to three-dimensional cohesion of the structure. The hydroxide group $\mathrm{O} 1-\mathrm{H} 1$ of a ribbon above the interlayer is also close to an $\mathrm{O} 7$ $(\mathrm{O} 1 \cdots \mathrm{O} 7=2.809 \AA)$ in a 'water' segment. In a sulfate segment, $\mathrm{O} 1$ of the 'upper' ribbon is close to O5 of a 'lower' sulfate $(2.570 \AA)$ and vice versa; thus, each $\mathrm{O} 5$ receives $\mathrm{H}$ bonds from three hydroxide anions $(\mathrm{O} 1$ and $2 \times \mathrm{O} 3)$. However, $\mathrm{O} 1$ of the lower ribbon makes no $\mathrm{H}$ bond to a 'lower' 
sulfate, and similarly for the upper-upper combination. The remaining two hydrogen atoms $\mathrm{H} 4$ and
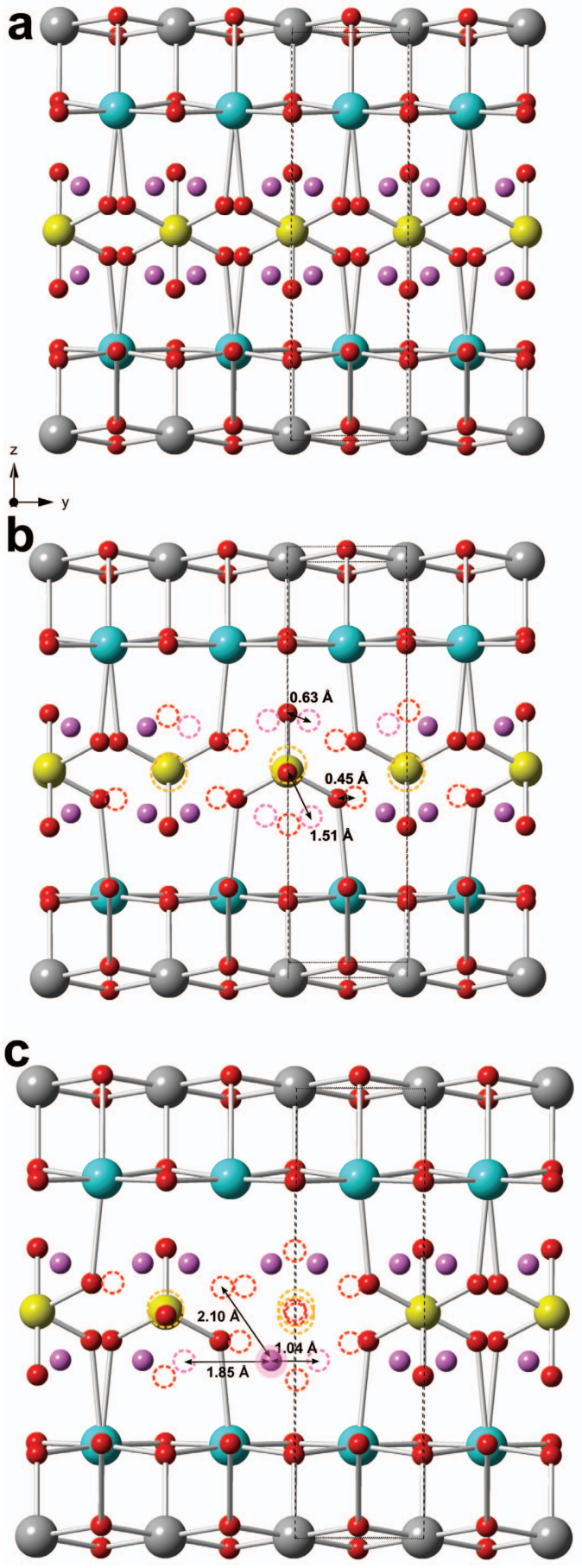

H5 form a water molecule with O7. As noted above, $\mathrm{O} 7$ accepts two hydrogen bonds from $\mathrm{H} 1$ and H3. Through $\mathrm{H} 4$ and H5, the water molecule must donate to sulfate oxygen atoms, and there are short distances $07 \cdots \mathrm{O} 4=2.808 \AA$ and $07 \cdots \mathrm{O} 6=$ $2.766 \AA$ which indicate the probable location of $\mathrm{O} 7-\mathrm{H} 4 \cdots \mathrm{O} 4$ and $\mathrm{O} 7-\mathrm{H} 5 \cdots \mathrm{O} 6$ bonds. Brown and Altermatt (1985) indicate that $\mathrm{O} \cdots \mathrm{O}$ of $2.8 \AA$ may still be associated with a $\mathrm{H}$ bond of valence $\sim 0.18$ vu. Each $\mathrm{O} 7$ also has up to two $\mathrm{O} 7$ neighbours at $2.895 \AA$, but these are probably not $\mathrm{H}$ bonded to it, as two donor and two acceptor ligands have already been identified. The coordinates of the $\mathrm{H}$ atoms may be estimated approximately, if they are assumed to lie $\sim 1.0 \AA$ from their primary oxygen, along a vector pointing towards their acceptor oxygen (Table 6).

The most symmetrical occupancy pattern along a $\mathrm{SO}_{4}-\mathrm{H}_{2} \mathrm{O}$ rod that satisfies the short-range order conditions is shown in Fig. 5, along with the associated $\mathrm{H}$-bonding pattern. Note that all $\mathrm{H}_{2} \mathrm{O} \mathrm{O} 7$ oxygen atoms make two short bonds and two long bonds to $\mathrm{H}$ atoms, and that all sulfate oxygen atoms are hydrogen bonded: $\mathrm{O} 4$ to one $\mathrm{H}, \mathrm{O} 5$ to three $\mathrm{H}$ and $\mathrm{O} 6$ to two $\mathrm{H}$. Receipt of more than one $\mathrm{H}$ bond is consistent with the low bond-valence sums seen for $\mathrm{O} 5$ and $\mathrm{O} 6$ in Table 5. The periodicity of this rod along $b$ is quadruple that of the average structure (Fig. $5 a$ ). Note that there is probably a strong preference for regular alternation of upper and lower sulfates, as deviation from that pattern would require rearrangement of the associated water molecules, omission of some $\mathrm{H}_{2} \mathrm{O}$ to avoid impossibly close contacts and loss of some $\mathrm{H}$ bonding. The location of the $\mathrm{H}_{2} \mathrm{O}$ at $\mathrm{O} 7$ makes impossible any local ordering pattern with $2 b$ periodicity, as was proposed by Mills et al. (2014).

\section{$4 b$ superstructure of cyanotrichite}

As the upper and lower sulfate atoms of Fig. 5 could be related by a $2_{1}$ screw axis derived from the diad axis of the average structure, a long-range

FIG. 4. (a) Ball-and-stick view of $\mathrm{SO}_{4}-\mathrm{H}_{2} \mathrm{O}$ rod in average structure. (b) If central $\mathrm{SO}_{4}$ tetrahedron adopts 'lower' orientation, then the interpenetrating upper $\mathrm{SO}_{4}$ and two adjacent lower $\mathrm{SO}_{4}$ groups must be absent, along with the six nearest $\mathrm{O} 7$ sites. The missing atoms are indicated by dashed circles and some impossible interatomic distances indicated. (c) If the highlighted $\mathrm{O} 7$ site is occupied, then three nearby $\mathrm{SO}_{4}$ and two $\mathrm{O} 7$ at the same height must be absent. 
ordered $P 2_{1} / a$ superstructure with such an arrangement would be possible, in which adjacent rods along the a direction are related by the glide plane. The $\mathbf{a} / 2+\mathbf{b} / 2$ lattice vector of the $C$-centred average structure becomes $\mathbf{a} / 2+n \mathbf{b} / 8(n=$ odd $)$ in the $4 b$ superstructure, which is not a potential lattice vector, so the supercell is necessarily primitive. The occupation pattern along the $\mathbf{b}$ direction in Fig. $5 a$ can be described as '-/-L-/-U-/L-I-U-', where 'L' = lower sulfate tetrahedron, 'U' $=$ upper sulfate, ' $/$ ' = lower-left and upper-right $\mathrm{H}_{2} \mathrm{O}$, 'I' = upper-left and lower-right $\mathrm{H}_{2} \mathrm{O}$.
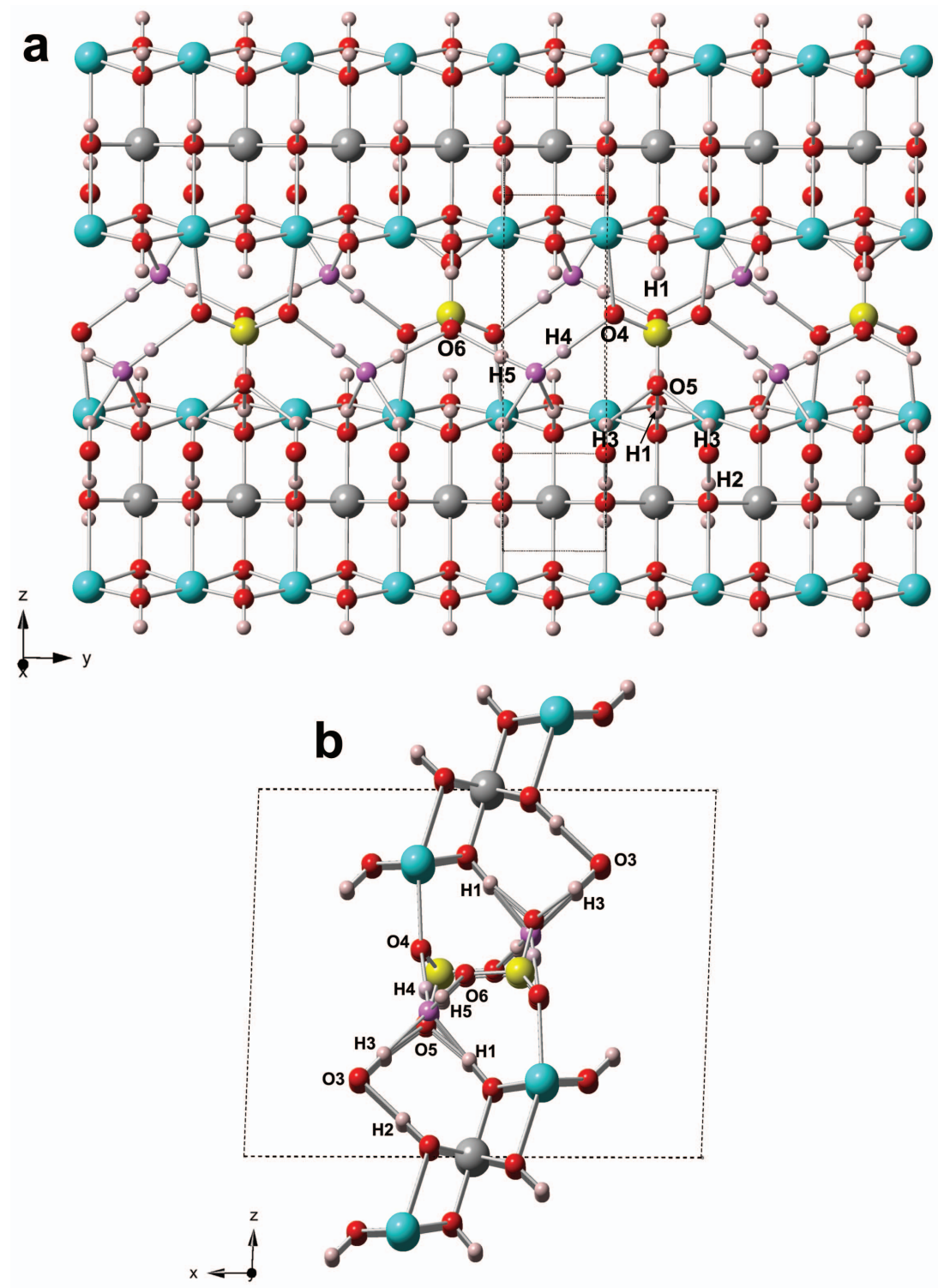

FIG. 5. (a) The most symmetrical way of occupying $\mathrm{SO}_{4}$ and $\mathrm{H}_{2} \mathrm{O}$ sites along a rod. Hydrogen atoms are shown as small, light pink spheres. All water molecules O7 (dark pink) have two donor and two acceptor $\mathrm{H}$ atoms. Sulfate O4 receives a hydrogen bond from $\mathrm{H} 4, \mathrm{O} 5$ receives three from $\mathrm{H} 1$ and two $\mathrm{H} 3$, $\mathrm{O} 6$ receives two from $\mathrm{H} 5$. Note that the upper $\mathrm{H} 1$ indicated cannot make an $\mathrm{H}$ bond to either $\mathrm{O} 5$ or O7. (b) View down $\mathbf{b}$ axis of the structure seen in $(a)$, showing that the $\mathrm{O} 3-\mathrm{H} 3$ hydroxides bonding to $\mathrm{O} 5$ actually belong to the adjacent ribbons in \pm a directions. 


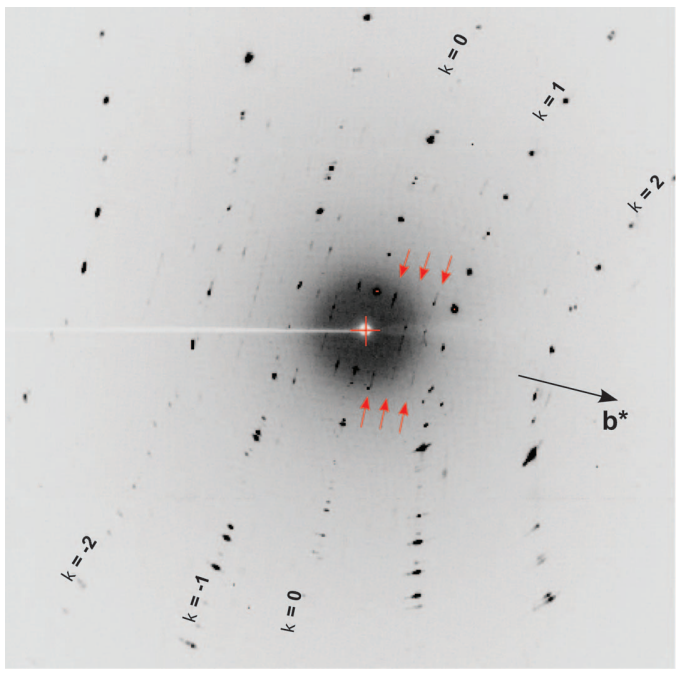

FIG. 6. Synchrotron X-ray diffraction pattern from the Cap Garonne cyanotrichite, showing the diffuse $4 b$ superstructure. The approximate $\mathbf{b}^{*}$ direction is indicated by large black arrow; small red arrows highlight examples of additional scattering due to the superstructure.
There is little driving force for coupling of the phase between neighbouring interlayer rods, so additional scattering due to the $4 b$ period is likely to be diffuse rather than sharp. However, shortrange ordering might result in the condensation of the diffuse scattering into streaks or spots. Mills et al. (2014) noted the observation of such data for one cyanotrichite crystal from the Cap Garonne mine, Le Pradet, Var départment, France. The additional scattering occurred in well defined layers of reciprocal space with $k=n / 4(n=$ integer) and took the form of well-defined spots superimposed upon streaking within the reciprocal lattice layers (Fig. 6). There was no indication of increased periodicity along a or $\mathbf{c}$ directions.

The simplest interpretation of the additional scattering is that the interlayer rods of this cyanotrichite have a quadrupled periodicity $\| \mathbf{b}$, with some tendency for neighbouring rods to order in phase relative to their neighbours, so that ordered domains give rise to relatively sharp superlattice reflections. The streaking parallel to the $\mathbf{a}^{*}-\mathbf{c}^{*}$ plane implies that some local ordering patterns do not have monoclinic symmetry. The structure within the $\mathrm{Cu}-\mathrm{Al}$ layers $\|(001)$ has a (pseudo-) $\mathrm{C}$-centred rectangular mesh that cannot

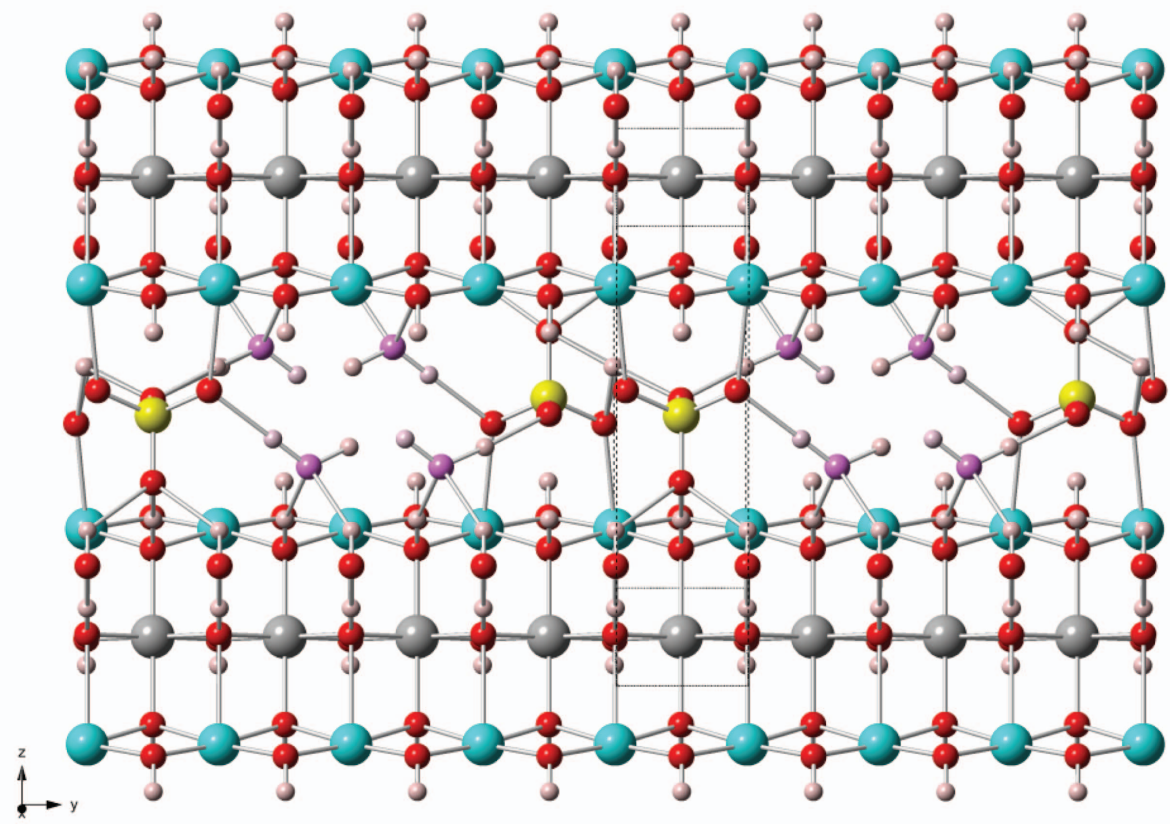

FIG. 7. Atomic arrangement along the $\mathrm{SO}_{4}-\mathrm{H}_{2} \mathrm{O}$ rod viewed nearly down a, if upper and lower $\mathrm{SO}_{4}$ tetrahedra are adjacent (compare Fig. 5a). 
shear significantly (cf. Fig. 3c). However, strongly triclinic unit-cell metrics can be generated if equivalent positions related by $\mathbf{c}$ are displaced relative to one another in the $\mathbf{b}$ direction, thus giving $\alpha \neq 90^{\circ}$. There are two ways that this can occur: (1) interlayer $\mathrm{SO}_{4}-\mathrm{H}_{2} \mathrm{O}$ rods with periodicity $b^{\prime}=4 b$ may be out of phase by $n b^{\prime} / 4$ relative to their neighbours in the $\mathbf{c}$ direction, in an ordered fashion; (2) interlayer rods may shear, so that $\mathrm{Cu}-\mathrm{Al}$ layers are displaced relative to their neighbours in the $\mathbf{c}$ direction by amounts that are not necessarily commensurate with the $b$ repeat. Such a displacement occurs in camerolaite (Mills et al. 2014).

Note that the observed superperiod is completely commensurate and occurs along a direction that is within the plane of the structural layers. The $4 b$ superperiod is thus independent of the state of stacking order of the layers, in contrast to a typical layered polytypic system, in which stacking order-disorder (OD) produces superperiodicity and/or loss of periodicity along a direction normal to the layers. The distinction between these two causes of superperiodicity is highlighted in the sapphirine group of aluminosilicate minerals, where structural layers \| (010) may be stacked with combinations of two stacking vectors to give $1 b, 2 b, 3 b, 4 b$ or $5 b$ periodicity or disorder along the $\mathbf{b}$ direction (Christy and Putnis, 1988), but quite independently, cation ordering within the layers causes doubled periodicity in an orthogonal direction in the related mineral khmaralite (Christy, 1988, 2009; Barbier et al. 1999).

The strong flux of the synchrotron allowed a large number of indexable spots from the $4 b$ supercell to be harvested from the Cap Garonne sample. However, the additional reflections were not of sufficient quality to enable a full refinement. Because of the probable displacement of maxima for strongly streaked superstructure spots, only strong, sharp substructure reflections were used to refine the cell parameters. This yielded the following cell: $a=12.611(2) \AA, b=$ $11.584(16)=4 \times 2.896(4) \AA, c=10.190(1) \AA$ and $\beta=92.29(6)^{\circ}$. The superstructure spots of the Cap Garonne cyanotrichite imply that it approximates a state of long-range order with $P 2 / m$ space group rather than $P 2_{1} / a$, as might be expected from the discussion above. This is unexpected, as the observed subgroup of the $C 2 / m$ subcell symmetry does not permit full order of the sulfate tetrahedra. The diad axes of $P 2 / m$ interconvert the mutually exclusive, interpenetrating 'upper' and 'lower' sulfate tetrahedra, so a $P 2 / m$ $4 b$ superstructure must retain complete long-range disorder of 'upper' and 'lower' sulfates. Representing 'upper' and 'lower' tetrahedra by ' $U$ ' and ' $L$ ' as before and disordered tetrahedra as ' $T$ ', the quadrupling of the $b$ repeat cannot arise from the obvious ordering pattern '-U- $\square$-L- $\square$-U- $\square$ L- $\square$-' along rods, as $P 2 / m$ symmetry does not allow ' $T$ ' to be separated into ' $U$ ' and ' $L$ '. Instead, quadrupling the $b$ repeat requires the ordering pattern '-T-T- $\square-\square-\mathrm{T}-\mathrm{T}-\square-\square$-'. Although the ' $\mathrm{T}$ ' implies that there is no longrange order of sulfate orientation, the occurrence of sulfate groups in adjacent pairs along $\mathbf{b}$ implies that each '-T-T-' pair must be realized as either '-U-L-' or '-L-U-', as two 'U' tetrahedra or two ' $L$ ' cannot occur next to one another (see above). As before, a given rod is likely to be consistent, with either '-L-U' or '-U-L' pairs only, as change between the two requires omission of some $\mathrm{H}_{2} \mathrm{O}$ molecules and hydrogen bonds. A possible atomic arrangement is shown in Fig. 7. Using the same symbology as before, the rod structure of Fig. 7 can be described as 'L-I-I-U-L-I-I-U-'. Note that the local bonding patterns are very similar to those of Fig. $5 a$, except that one hydrogen of each water molecule does not donate to a hydrogen bond: either the link $\mathrm{O} 7-\mathrm{H} 4 \cdots \mathrm{O} 4$ exists for a given water molecule, or $\mathrm{O} 4-\mathrm{H} 5 \cdots \mathrm{O} 6$, but not both.

In a $4 b$ supercell with $P 2 / m$ symmetry, rods such as those of Fig. 7 must be in phase with those at $\pm \mathbf{a}$, although ' $U$ ' and ' $L$ ' may be exchanged, and likewise 'I' with '/' configurations. It is probable that the same pattern occurs for both $\mathrm{SO}_{4}-\mathrm{H}_{2} \mathrm{O}$ rods of the supercell, which are translated relative to one another by vectors $\mathbf{a} / 2 \pm \mathbf{b} / 8$ or $\mathbf{a} / 2 \pm 3 \mathbf{b} / 8$. As these are no longer lattice vectors and the supercell possesses neither screw diads nor glide planes, the two $\mathrm{SO}_{4}-\mathrm{H}_{2} \mathrm{O}$ rods of each unit cell are symmetrically independent of one another. The ordered arrangements of sulfate groups and remanent disorder that correspond to $C 2 / m 1 b$ average structure and the $P 2_{1} / a$ and $P 2 / m \quad 4 b$ superstructures are compared in Fig. 8.

The diagram of Fig. 8e shows one of the specific local configurations in an interlayer that contributes to the $P 2 / m$ average structure. This configuration is not compatible with any of the symmetry elements of the latter space group, so the true local symmetry is triclinic. As adjacent rods along the a direction are not related by 

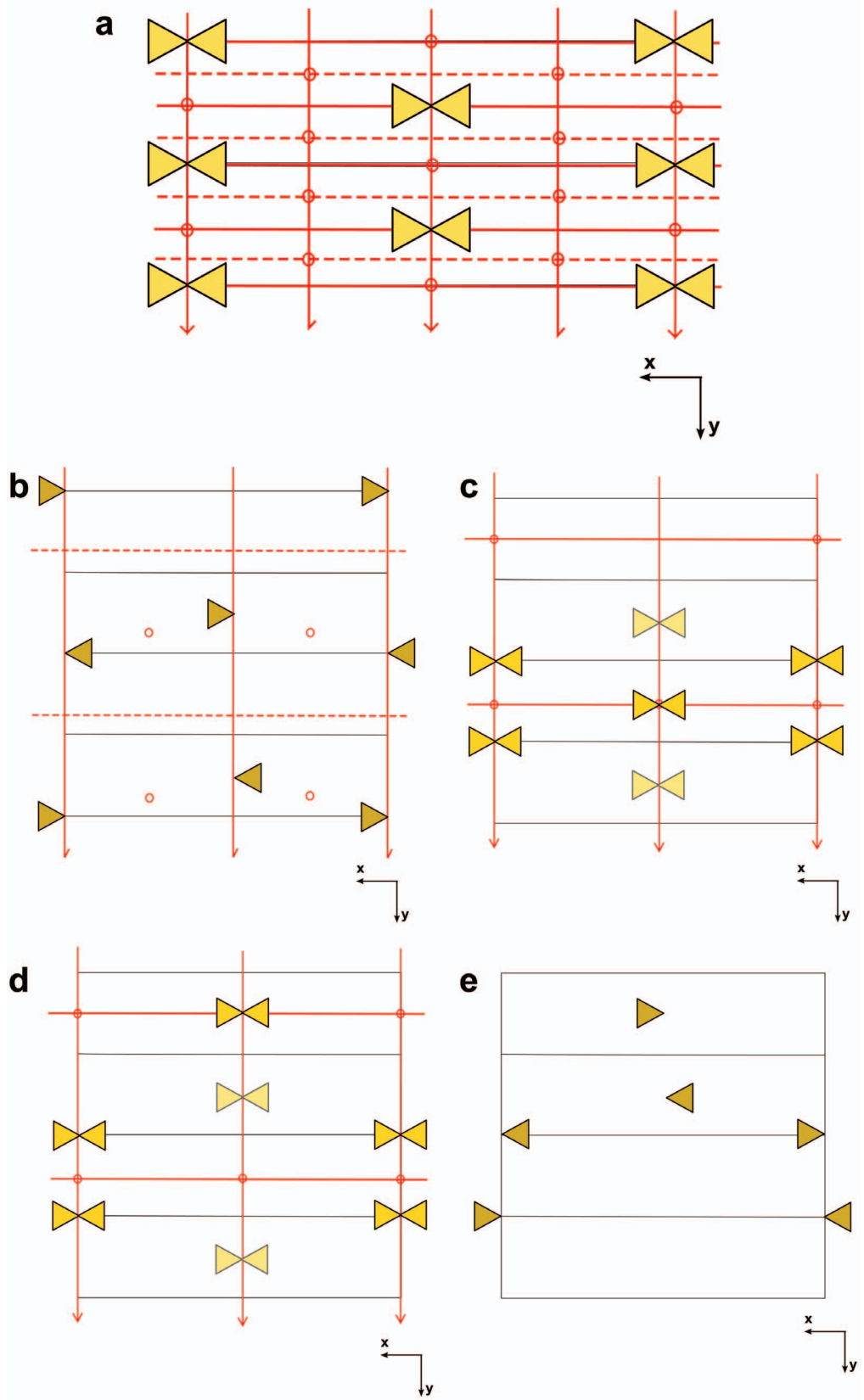

FIG. 8. (a) Schematic view of two unit cells of the $C 2 / m$ average structure of cyanotrichite. Left- and right-pointing triangles indicate lower and upper orientations of sulfate tetrahedra, respectively. Each tetrahedron is $25 \%$ occupied. Unit-cell edges are indicated by black lines, symmetry elements (diad and screw axes, mirror and glide planes, centres of inversion) are indicated in red. (b) Hypothetical fully ordered $4 b$ superstructure with space group $P 2{ }_{1} / a$ (darker colour indicates $100 \%$ occupied sulfate tetrahedra). (c) One possible $4 b$ structure with $P 2 / m$ symmetry. Adjacent ribbons are shifted by $\mathbf{a} / 2 \pm \mathbf{b} / 8$. Darker triangle pairs are $25 \%+25 \%$ occupied; paler colour indicates $12.5 \%+12.5 \%$ occupation. $(d)$ The other $P 2 / m$ arrangement. Adjacent ribbons are shifted by a/2 $\pm 3 \mathbf{b} / 8$. (e) The long-range structure of $(d)$ corresponds to a superposition of several local configurations such as this (all tetrahedra $100 \%$ occupied). 
symmetry, while every second rod is equivalent, it is cumbersome to attempt to describe the structural variation in terms of OD theory: there are eight distinct positions for the sulfate pair of the $x=1 / 2$ rod relative to the rods at $x=0$ and 1 , and all are effectively MDO (maximum degree of order) structures of equal $P 1$ symmetry. The number of 'maximally ordered' structures is further proliferated by the possibility of ordered displacements $\| \mathbf{b}$ of successive interlayers, as discussed above. Given the large number of local configurations available, it is no surprise that long-range order does not occur.

Note that the occurrence in Cap Garonne cyanotrichite of the local ordering pattern of Fig. 7 does not exclude the possibility that other local ordering patterns (e.g. that of Fig. 5) may occur elsewhere. The differences in IR spectra between Maid of Sunshine and Cap Garonne samples (Fig. 2b) suggest that local $\mathrm{H}_{2} \mathrm{O}$ environments are different for the two. Unfortunately, for samples where there is no additional scattering due to short- or long-range order, we have no data on the local arrangement of sulfate and water groups.

\section{Conclusions}

We present the first structure refinement of cyanotrichite, in which all atoms except hydrogen were located. The Maid of Sunshine crystal studied showed no evidence of a superstructure and had the maximum possible $C 2 / m$ symmetry. The refinement confirms that the cyanotrichite structure follows the principles previously deduced for the cyanotrichite group, in that translationally disordered rods of anions are intercalated between ordered layers of edgesharing Cu-rich polyhedra (Hager et al., 2009; Mills et al., 2014). This type of disorder is shared with the chemically and structurally related mineral parnauite, $\mathrm{Cu}_{9}\left[\mathrm{AsO}_{4}\right]_{2}\left[\mathrm{SO}_{4}\right](\mathrm{OH})_{10}$ $\cdot 7 \mathrm{H}_{2} \mathrm{O}$ (Mills et al., 2013).

In contrast to the closely related mineral camerolaite (Mills et al. 2014), the structural water oxygen $\mathrm{O} 7$ is not bonded to the $\mathrm{Cu}$ atom in cyanotrichite, but instead forms hydrogen bonds to the sulfate tetrahedra. A hydrogen-bonding scheme was deduced, which allows approximate location of the hydrogen atoms.

A second crystal was studied that did show diffraction streaks and spots consistent with an incipient $4 b$ superstructure. The superstructure could not be refined, but its $P 2 / m$ space group indicated that the occupation pattern of $\mathrm{SO}_{4}$ along any given row $\|$ b must be (- $\square$ - $\square$-L-U- $\square$ - $\square$-L-U-) rather than (- $\square$-L- $\square$-U- $\square$-L- $\square$-U-), where 'L' indicated 'lower' and ' $U$ ' is 'upper' out of the two mutually exclusive $S$ sites. A very large number of localordering patterns (all of triclinic symmetry) satisfy this condition, which prevents long-range order.

The unexpected location of the $\mathrm{O} 7$ atom means that half the $\mathrm{Cu}$ atoms have only 5 -fold rather than octahedral coordination, and it is better to regard the ordered building unit of the cyanotrichite group as a mixed-coordination $\left[\mathrm{Cu}_{2} \mathrm{Al}(\mathrm{OH})_{6}\right]$ ribbon rather than a fully octahedral $\left[\mathrm{Cu}_{2} \mathrm{Al}\left(\mathrm{OH}, \mathrm{O}, \mathrm{H}_{2} \mathrm{O}\right)_{8}\right]$ ribbon. The smaller building unit is compositionally constant for all members of the group, and allows all oxygen atoms of interlayer anions such as sulfate to be regarded as separate from the $\mathrm{Cu}-\mathrm{Al}$ ribbon. Ideal formulae can be written $2\left[\mathrm{Cu}_{2} \mathrm{Al}(\mathrm{OH})_{6}\right]^{+}+$ $\left[\mathrm{SO}_{4}\right]^{2-}+2\left(\mathrm{H}_{2} \mathrm{O}\right)=$ cyanotrichite, $3\left[\mathrm{Cu}_{2} \mathrm{Al}(\mathrm{OH})_{6}\right]^{+}+\left[\mathrm{Sb}(\mathrm{OH})_{6}\right]^{-}+\left[\mathrm{SO}_{4}\right]^{2-}+$ $2\left(\mathrm{H}_{2} \mathrm{O}\right)=$ camerolaite and $4\left[\mathrm{Cu}_{2} \mathrm{Al}(\mathrm{OH})_{6}\right]^{+}+$ $\left[\mathrm{Al}_{2} \mathrm{~F}_{6}\left(\mathrm{H}_{2} \mathrm{O}\right)_{4}\right]^{0}+4 \mathrm{OH}^{-}=$khaidarkanite.

\section{Acknowledgements}

The Associate Editor, Diego Gatta and two anonymous reviewers are thanked for their constructive comments on the manuscript which helped to improve it. Rosemary Goodall is thanked for help with obtaining the IR data. Bill Birch is thanked for taking the photomicrograph of the cyanotrichite sample.

\section{References}

Barbier, J., Grew, E.S., Moore, P.B. and Su, S.-C. (1999) Khmaralite, a new beryllium-bearing mineral related to sapphirine: a superstructure resulting from partial ordering of $\mathrm{Be}, \mathrm{Al}$ and $\mathrm{Si}$ on tetrahedral sites. American Mineralogist, 84, 1650-1660.

Brese, N.D. and O'Keeffe, M. (1991) Bond-valence parametrers for solids. Acta Crystallographica, B47, 192-197.

Brown, I.D. and Altermatt, D. (1985) Bond-valence parameters obtained from a systematic analysis of the Inorganic Crystal Structure Database. Acta Crystallographica, B41, 244-247.

Bruker (2001) SAINT Version 6.02 (includes XPREP and $S A D A B S$ ). Bruker AXS Inc., Madison, Wisconsin, USA.

Christy, A.G. (1988) A new $2 c$ superstructure in beryllian sapphirine from Casey Bay, Enderby Land, Antarctica. American Mineralogist, 73, $1134-1137$.

Christy, A.G. (2009) A Monte Carlo study of short- and 


\section{CRYSTAL STRUCTURE OF CYANOTRICHITE}

long-range order of tetrahedral cations in sapphirine and khmaralite. American Mineralogist, 94, 270-282.

Christy, A.G. and Putnis, A. (1988) Planar and line defects in the sapphirine polytypes. Physics and Chemistry of Minerals, 15, 548-558.

Hager, S.L., Leverett, P. and Williams, P.A. (2009) Possible structural and chemical relationships in the cyanotrichite group. The Canadian Mineralogist, 47, 635-648.

Hawthorne, F.C., Krivovichev, S.V. and Burns, P.C. (2000) The crystal chemistry of sulfate minerals. Pp. 1-112 in: Sulfate Minerals: Crystallography, Geochemistry and Environmental Significance (C.N. Alpers, J.L. Jambor and D.K. Nordstrom, editors). Reviews in Mineralogy, 40. The Mineralogical
Society of America, Washington, DC.

Kabsch, W. (2010) XDS. Acta Crystallographica, D66, 125-132.

Mills, S.J., Kampf, A.R., McDonald, A.M., Bindi, L., Christy, A.G., Kolitsch, U. and Favreau, G. (2013) The crystal structure of parnauite: a copper arsenatesulphate with translational disorder of structural rods. European Journal of Mineralogy, 25, 693-704.

Mills, S.J., Christy, A.G., Schnyder, C., Favreau, G. and Price, J.R. (2014) The crystal structure of camerolaite and structural variation in the cyanotrichite family of merotypes. Mineralogical Magazine, 78, $1501-1526$.

Sheldrick, G.M. (2008) A short history of SHELX. Acta Crystallographica, A64, 112-122. 
